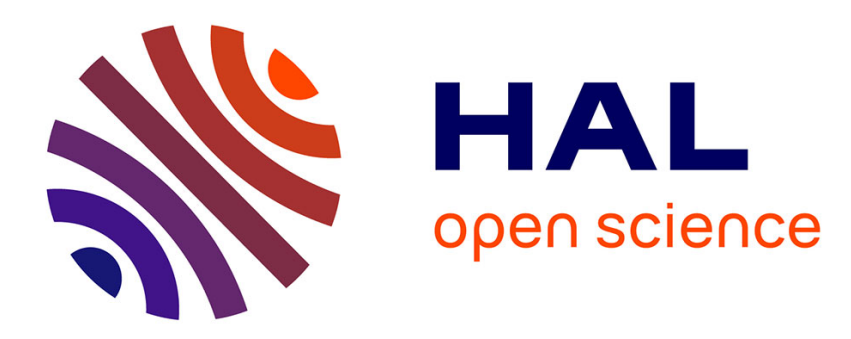

\title{
Gender, Transformation and Employment in Central Eastern Europe
}

Anna Pollert

\section{To cite this version:}

Anna Pollert. Gender, Transformation and Employment in Central Eastern Europe. European Journal of Industrial Relations, 2005, 11 (2), pp.213-230. 10.1177/0959680105053964 · hal-00570938

\section{HAL Id: hal-00570938 \\ https://hal.science/hal-00570938}

Submitted on 1 Mar 2011

HAL is a multi-disciplinary open access archive for the deposit and dissemination of scientific research documents, whether they are published or not. The documents may come from teaching and research institutions in France or abroad, or from public or private research centers.
L'archive ouverte pluridisciplinaire HAL, est destinée au dépôt et à la diffusion de documents scientifiques de niveau recherche, publiés ou non, émanant des établissements d'enseignement et de recherche français ou étrangers, des laboratoires publics ou privés. 


\title{
Anna Pollert
}

London Metropolitan University, UK

\section{Gender, Transformation and Employment in Central Eastern Europe}

\begin{abstract}
This article discusses gender and employment in 10 central eastern European countries: eight new EU member states and two candidate countries. The context is set with demographic, economic, and labour-market trends, including population, GDP, and gender disaggregated employment, activity, and unemployment rates. Changes in horizontal and vertical gender segregation are then addressed, especially the uneven gender effect on employment patterns of sectoral restructuring during capitalist transformation. Lastly, the gender pay gap is examined, and compared to patterns in western Europe. The article concludes with a discussion of the advances, but also the limits of harmonization through EU gender-equality legislation.
\end{abstract}

\section{Introduction}

How have 15 years of capitalist transition in the new EU member states from the former communist bloc affected gender relations, including those at work, and how does the current position compare with that in western Europe? This article presents a study of gender and employment in 10 central eastern European countries (CEECs) from early capitalist transformation (and where possible from the communist era) to the present. Data were gathered for the European Foundation for the Improvement of Living and Working Conditions by research teams from eight new member states (the Czech Republic, Estonia, Hungary, Latvia, Lithuania, Poland, Slovakia and Slovenia) and the two candidate countries scheduled to accede in 2007 (Bulgaria and Romania). ${ }^{1}$ The purpose was to analyse Labour Force Survey (LFS) data and to provide a benchmark with which to evaluate the Foundation's own survey of the CEECs (European Foundation, 2003).

The first part of the article addresses broad demographic, economic, and labour-market trends, including population, GDP, human development 
indices, and gender disaggregated employment, activity and unemployment rates. The next section explores gender segregation, presenting snapshots for 1990, 1995, and 2001. Analysis begins with economic and sectoral restructuring, to frame the subsequent study of horizontal gender segregation within overall changing employment patterns. Standard NACE (nomenclature générale des activités économiques) categories are available from 1990 for some countries, and for others only from 1995. Occupational segregation is then explored using the International Standard Classification of Occupations (ISCO-88). Lastly, the gender pay gap is explored.

\section{Demographic, Economic and Employment Trends}

The CEEC-10 vary widely in population, ranging from 38.6 million in Poland to 1.3 million in Estonia. In all countries there are more women than men, and in most, the population is declining (by as much as 1 million between 1985 and 2001 in Bulgaria). Only Poland and Slovakia show an increase, but this took place between 1985 and 1990 and then stagnated. The trend reflects declining birth rates, notably in Poland and Slovakia. Average life expectancy for both sexes remains below the 'High Human Development' level of more than 75 years for the advanced capitalist world, except in Slovenia and the Czech Republic (75.9 and 75.1). Male life expectancy remains in the mid-sixties, and for females in the mid-seventies, whereas in most of western Europe it is in the midseventies for men and around 80 for women (UNDP, 2001, 2003).

In the early transition years, all countries were affected by recession; and although most were recovering by 2002, GDP in Bulgaria, Estonia, Latvia, Lithuania, and Romania was still below the 1989 level. There is wide disparity in per capital income: in Bulgaria, at one extreme, it is only 24 percent of the EU-15 average, while in Slovenia, at the other, it is 71.5 percent. However, averages can obscure inequality and poor living standards; here the United Nations Human Development Index (HDI) is a better guide, and the Gender Development Index (GDI) shows the position of women relative to men on a number of life-course dimensions (UNICEF, 1999). ${ }^{2}$

When a GDI was first calculated in 1991, it was evident that CEECs ranked high internationally in gender equality, 10-15 places higher than their HDI position. Key factors contributing to the communist genderequality legacy were women's high educational levels, state support for childcare and working mothers and women's high labour force participation rate. ${ }^{3}$ After 1995, GDI rank dropped, while HDI started to rise with economic recovery, and in those countries which developed fastest towards free-market capitalism (such as the Czech Republic, Hungary 
and Poland), HDI and GDI ranks converged - the typical pattern for western economies. However, in the Balkan and Baltic states, GDI remained higher than HDI. Romania still lagged at seventy-second place out of 100 in HDI in 2001, but its GDI ranking was 15 points higher at 57 (UNDP, 2003: 311). The less advanced in capitalist development terms, the stronger the communist gender-equality legacy. This confirms the argument that despite the well-established limitations to advances for women during the command-economy era, capitalist development has brought deterioration (Einhorn, 1993).

Because of job losses for both men and women since 1989, employment rates (except in Hungary and Slovenia) were lower in 2001 than in 1995, although close to the EU-15 average of about 60 percent (Eurostat, 2002: 15). Declines were sharpest between 1990 and 1995, and less pronounced in the second half of the decade.

A feature of communist development was the early integration of women into the labour force. Whereas women's share of employment was only between 35 and 45 percent in OECD countries in the mid1980s, these levels were already achieved by the late 1960s in the CEECs. Although women still constitute around 45 percent of the labour force, there has been a decline in the female activity rate (employed plus unemployed as a percentage of the working-age population). In 1989, this ranged between 70 and 90 percent of working-age women ( $15-55$ years), similar to the Swedish level. Across the EU-15 at that date the figure was only 50 percent, though measured across the age range 15-64; for the 'prime-age' group of 25-54, the proportion was 60 percent, still well below the CEEC level (EC, 2002; UNICEF, 1999: 24). The largest fall in the female activity rate was in Hungary: from 76 to 50 percent between 1990 and 1995, with only slight recovery to 52 percent in 2001. Male activity dropped too: from 84 to 68 percent. Many women began to work informally and became invisible to labour-market statistics. The fall in female activity under post-communism is a key factor in the decline in the GDI.

Unemployment ${ }^{4}$ is the more visible aspect of labour-market change, with steep rises since 1990, and signs of decreases by 2001 only in Hungary (where the activity rate has, however, fallen to 60 percent), Latvia, Slovenia, and Romania (where there exists a large number of informal jobs in agriculture). The 'lowest' rates in 2001 were in Slovenia, Romania, Hungary, and the Czech Republic, ranging between 5.6 and 8 percent; other countries, such as Bulgaria and Slovakia, suffered rates in the region of 20 percent. In the EU-15, the average had decreased to 7.4 percent by 2001 (EC, 2002: 173; Eurostat, 2002: 16). In many CEECs, women's unemployment rate is higher than that for men, as in the EU15, and the gender gap has been widening in the Czech Republic, Poland, and Slovenia. The reverse is occurring in Bulgaria and Lithuania, where 
female unemployment is now lower than that of males, but female activity rates have also decreased. In most countries, women were also overrepresented among the unemployed compared with their percentage of the employed. ${ }^{5}$ The exception was Hungary, but this again reflects the exceptionally large drop in female activity rates. In Slovenia, the relatively better position of women was reversed after 1995, when they too became overrepresented among the unemployed.

In sum, it is evident that whether unemployed or no longer part of the labour force, women's legacy of strong integration in paid work has been adversely affected by the decline in publicly funded support for working mothers and children. Country reports show that women's marginalization is closely associated with the growing conflict between their reproductive role and employment, and the effects of life-cycle changes on their ability to find and remain in employment. The Polish report shows very high unemployment among those aged 15-34, but among these, women are overrepresented. The Czech report shows that the proportion of unemployed women tripled between 1995 and 2001 in the 15-19, 35-39, and 50-54 age groups, categories that roughly correspond to the periods in the life and family cycles of women when they most frequently encounter problems in the labour market (low education and unemployment among secondary-school graduates, responsibilities for pre-school children or more than one child, and pre-retirement age). Long-term unemployment is also higher among women than men.

\section{Gender Segregation}

Capitalist economic relations have been introduced in contexts varying from highly agricultural Romania, Poland and Lithuania (41, 29, and 17 percent employment in agriculture, respectively) to more industrialized countries such as the Czech and Slovak Republics, Estonia and Hungary, where agricultural employment in 2001 was similar to the EU-15 average of 4.2 percent (see Table 1). In all CEECs, apart from Poland and Romania, the agricultural sector has declined since transition. Employment in industry has also declined: in most cases, according to Eurostat (2002: 20), by around 5 percent, but in Romania by 15 percent. Our country reports show greater variation, with the largest decline in Estonia (16.7 percent) and the smallest in the Czech Republic, Slovenia and Hungary. Industry now employs between 20 and 33 percent of employees in these countries, matching the EU-15 average of 26.4 percent (EC, 2002: 173).

Service-sector employment (except in Romania and Poland) is close to the EU-15 share of 69.4 percent. But while private services have expanded everywhere, the public sector has stagnated, and in several countries 
TABLE 1. Employment by Sector (\%)

\begin{tabular}{|c|c|c|c|c|c|c|c|c|c|c|c|c|}
\hline & \multicolumn{4}{|c|}{$1990^{a}$} & \multicolumn{4}{|c|}{$1995^{b}$} & \multicolumn{4}{|c|}{2001} \\
\hline & Agriculture & Industry & Services & $\begin{array}{l}\text { Public } \\
\text { services }\end{array}$ & Agriculture & Industry & Services & $\begin{array}{l}\text { Public } \\
\text { services }\end{array}$ & Agriculture & Industry & Services & $\begin{array}{l}\text { Public } \\
\text { services }\end{array}$ \\
\hline $\begin{array}{l}\text { Bulgaria } \\
\text { Czech }\end{array}$ & $\mathrm{n} / \mathrm{a}$ & $\mathrm{n} / \mathrm{a}$ & $\mathrm{n} / \mathrm{a}$ & $\mathrm{n} / \mathrm{a}$ & 12.4 & 30.3 & 27.8 & 24.1 & 9.7 & 27.8 & 32.8 & 24.7 \\
\hline Republic ${ }^{c}$ & 11.7 & 37.8 & 26.0 & 16.7 & 6.2 & 32.4 & 34.2 & 17.9 & 4.0 & 31.7 & 37.1 & 19.2 \\
\hline Estonia & 18.0 & 28.8 & 22.3 & 19.4 & 9.6 & 28.6 & 31.3 & 24.0 & 6.5 & 26.2 & 34.6 & 25.4 \\
\hline Hungary & 11.3 & 29.7 & 28.2 & 25.5 & 8.0 & 26.7 & 30.1 & 29.3 & 6.2 & 27.2 & 33.7 & 25.9 \\
\hline Latvia & $\mathrm{n} / \mathrm{a}$ & $\mathrm{n} / \mathrm{a}$ & $\mathrm{n} / \mathrm{a}$ & $\mathrm{n} / \mathrm{a}$ & 16.0 & 22.0 & 28.1 & 27.7 & 13.9 & 19.7 & 32.3 & 26.5 \\
\hline Lithuania & 19.5 & 28.8 & 20.4 & 22.1 & 23.7 & 21.2 & 23.3 & 24.7 & 17.0 & 20.7 & 28.3 & 27.1 \\
\hline Poland & 28.4 & 28.0 & $\mathrm{n} / \mathrm{a}$ & $\mathrm{n} / \mathrm{a}$ & 27.7 & 24.7 & 24.8 & 17.2 & 29.2 & 20.2 & 27.5 & 18.0 \\
\hline Romania & 29.0 & 36.9 & 17.7 & 9.9 & 40.2 & 26.7 & 14.8 & 13.8 & 40.8 & 23.5 & 19.1 & 12.6 \\
\hline Slovakia ${ }^{c}$ & 11.7 & 37.8 & 26.0 & 16.7 & 9.2 & 30.4 & 26.8 & 25.0 & 6.1 & 29.6 & 29.7 & 26.2 \\
\hline Slovenia & 10.7 & 38.7 & 25.3 & 19.3 & 10.4 & 38.1 & 27.3 & 18.9 & 9.8 & 32.2 & 30.0 & 20.8 \\
\hline
\end{tabular}

Notes: Agriculture: NACE 1; in some countries this includes fishing, NACE 2.

Industry: NACE 3, 4, and 5 (mining, manufacturing, electricity, gas, and water).

Services: NACE 7 Wholesale and retail trade; NACE 8 Hotels and restaurants; NACE 9 Transport, storage, and communication; NACE 10 Financial intermediation; NACE 11 Real estate, renting, and business.

Public Services: NACE 12 Public administration, defence, compulsory social security; NACE 13 Education; NACE 14 Health and social work;

NACE 15 Other community and social and personal service activities.

${ }^{a}$ Hungary and Lithuania 1992, Slovenia 1993.

b Bulgaria 1997, Latvia 1996.

c In 1990, the same figures are given for the Czech Republic and Slovakia because both formed the Czech and Slovak Federal Republic.

NB sector totals do not add up to 100 because of the omission of construction, a distinctive sector which does not clearly fit into any of the aggregated sectors presented here.

Source: Country Reports, Labour Force Surveys or earlier data. 
(Hungary, Latvia and Romania) employment declined between 1995 and 2001.

Since 1995 both men and women have experienced similar employment decline in agriculture, except in Romania where agricultural employment actually expanded (see Table 2). In industry, both men and women suffered similar, small declines, although there are quite wide differences between the more and less industrialized countries. In the CEEC-10, less than a quarter of employed women worked in industry in 2001, but around a third of men.

The expansion in private service employment was slightly larger for men than for women. By contrast, in public services there is a small and stable share of male employment (15-16 percent) and a large and growing share of women's employment (which is over a third). In the public sector, where women are already overrepresented, six countries show an increase in female representation, with only Poland showing a decrease between 1990 and 2001, while women's share of private service employment has either remained stable, gone down, or fluctuated, with only Latvia showing a slight increase.

Within private services, women's share declined between 1990 and 2001: in wholesale and retail trade from 68 to 54 percent in the CEEC10 as a whole, from 70 to 66 percent in hotels and restaurants, and from 77 to 64 percent in financial intermediation. There are national variations in this pattern, but where women have increased their representation in one sector, this has been small, and often outweighed by decline in another sector. Declines were most severe in financial intermediation.

By contrast, women still predominate in the public sector. The female share in education, health and social work is three-quarters, similar to the EU-15, except for Poland, where women's presence has declined to 60 percent. In general, women's high representation has increased further in education, from 72 to 76 percent, with rises to 82 percent in Estonia and Latvia and to more than 78 percent in Bulgaria, Lithuania and Slovakia. In health and social work, there has been a slight drop overall, from 82 to 79 percent, but in some countries, such as Hungary, Latvia and Lithuania, there have been slight rises (Pollert and Fodor, 2004: 76).

The 'defeminization' of some private services illustrates a different trajectory from postwar western Europe, where service-sector growth was associated with feminization and sexual segregation based largely on a polarization between female part-time and male full-time employment (discussed further later). Historical legacies have left other differences in patterns of gender segregation between East and West. Comparing CEEC-10 LFS data with European Foundation data from its third survey of the EU-15 (Fagan and Burchell, 2002: 24) provides a 'snapshot' for 2001 (see Table 3). The sectoral ranking of segregation is similar; but while male-dominated sectors are more male dominated in the West than 
TABLE 2. Percentage of Female and Male Workforce in Four Sectors, 1995 and 2001

\begin{tabular}{|c|c|c|c|c|c|c|c|c|c|c|c|c|c|c|c|c|}
\hline & \multicolumn{4}{|c|}{ Female 1995} & \multicolumn{4}{|c|}{ Female 2001} & \multicolumn{4}{|c|}{ Male 1995} & \multicolumn{4}{|c|}{ Male 2001} \\
\hline & Agriculture & Industry & Services & $\begin{array}{l}\text { Public } \\
\text { services }\end{array}$ & Agriculture & Industry & Services & $\begin{array}{l}\text { Public } \\
\text { services }\end{array}$ & Agriculture & Industry & Services & $\begin{array}{l}\text { Public } \\
\text { services }\end{array}$ & Agriculture & Industry & Services & $\begin{array}{l}\text { Public } \\
\text { services }\end{array}$ \\
\hline $\begin{array}{l}\text { Bulgaria } \\
\text { Czech }\end{array}$ & 10.6 & 28.7 & 26.8 & 32.0 & 7.1 & 27.2 & 31.8 & 32.2 & 13.9 & 31.6 & 27.7 & 17.1 & 12.0 & 28.3 & 33.8 & 17.7 \\
\hline Republic & 4.9 & 27.9 & 37.4 & 27.5 & 2.9 & 26.4 & 39.0 & 24.5 & 6.9 & 36.5 & 31.2 & 11.3 & 5.0 & 36.0 & 35.7 & 7.7 \\
\hline Estonia & 7.6 & 24.5 & 32.4 & 33.6 & 3.8 & 22.2 & 36.3 & 36.6 & 11.4 & 32.1 & 30.2 & 15.1 & 9.0 & 30.1 & 33.1 & 14.8 \\
\hline Hungary & 4.7 & 23.5 & 31.8 & 38.8 & 3.5 & 24.2 & 34.0 & 37.1 & 10.7 & 29.2 & 28.8 & 21.7 & 8.4 & 29.5 & 33.5 & 16.8 \\
\hline Latvia & 12.6 & 18.7 & 28.1 & 38.7 & 10.4 & 17.3 & 33.9 & 36.8 & 19.4 & 25.1 & 28.1 & 17.6 & 17.3 & 22.1 & 30.7 & 16.5 \\
\hline Lithuania & 16.5 & 18.5 & 29.0 & 34.0 & 12.9 & 19.6 & 25.7 & 40.5 & 31.0 & 23.9 & 17.4 & 15.4 & 21.5 & 22.0 & 29.1 & 15.0 \\
\hline Poland ${ }^{a}$ & 1.2 & 27.9 & 27.5 & 43.9 & 1.0 & 22.6 & 29.4 & 45.3 & 3.3 & 45.4 & 24.7 & 14.7 & 2.5 & 41.8 & 29.7 & 15.7 \\
\hline Romania & 46.2 & 22.9 & 14.5 & 15.0 & 47.4 & 19.9 & 15.9 & 15.8 & 35.1 & 30.0 & 15.0 & 13.0 & 41.1 & 23.3 & 22.4 & 12.8 \\
\hline Slovakia & 6.4 & 26.8 & 29.3 & 35.6 & 3.7 & 24.1 & 31.7 & 38.5 & 11.4 & 33.1 & 24.6 & 16.6 & 8.2 & 34.3 & 28.1 & 15.7 \\
\hline Slovenia & 10.0 & 33.9 & 27.0 & 27.0 & 9.6 & 27.3 & 31.4 & 30.2 & 11.2 & 42.9 & 24.4 & 12.6 & 9.6 & 37.2 & 29.2 & 13.5 \\
\hline CEEC-10 & 12.5 & 25.4 & 27.9 & 32.5 & 10.9 & 23.2 & 30.3 & 33.4 & 15.4 & 32.5 & 24.9 & 15.2 & 13.0 & 30.4 & 30.2 & 16.1 \\
\hline
\end{tabular}

Notes: a 1996 figures for 1995.

b NACE 1993 for 1995, 2002 for 2001.

Source: Research team country tables, LFS unless otherwise stated. CEEC-10 unweighted average. 
in the East, the female dominated public service sector is more female dominated in the East than in the West. The greatest contrasts are in manufacturing, which is far less sexually segregated in the postcommunist countries, and in finance, which is male dominated in the EU15, but female dominated in the CEEC-10. These differences can be explained by communist policies which favoured women's participation in manufacturing and in economics and finance. The evidence does not support the contention that there is less gender segregation in the accession countries than in western Europe (European Foundation, 2002: 3). Rather, it is of a different shape.

The patterns of occupational segregation in the post-communist countries have been generally stable since 1995 and are broadly similar to those in the EU-15. Women are similarly underrepresented in high-level managerial positions, with 35 percent in ISCO-88 Group 1 in 2001 (compared to 37 percent in the EU-15), a proportion which has changed little since transition. They are more heavily represented in clerical occupations (Group 4), at 77 percent (69 percent in the EU-15), and predominate among professionals (63 percent, as against 50 percent in the EU-15) (Fagan and Burchell, 2002: 18). Women's dominance is identical in East and West among service occupations (Group 5), at 67 percent.

Women's strong representation among professionals and associated occupations in eastern Europe reflects their educational gains during communism, but they failed to advance further up the occupational hierarchy. High educational attainment still holds. Overall, women employees are more likely to hold university degrees than men and those with post-secondary degrees are overrepresented in the employed populations, and these trends have increased since 1995. Women were especially highly represented as a proportion of graduate employees in some countries: in Latvia (63 percent), Lithuania (60 percent) and Hungary and Bulgaria (58 percent). Whether women's high educational attainment helps in their pay, as 'human capital' theory would suggest, is another question.

\section{Gender Segregation and Pay}

In the EU-15, the European Community Household Panel survey provides a source of comparable cross-national pay data; but finding comparable and longitudinal data for CEECs remains problematic. Our national research teams found disaggregated, sectoral gender data in various ways: sometimes from statistical year books, sometimes from special studies on men and women, and in some cases by specially calculated data from statistical offices. This variation means that cross-national comparisons need to be interpreted with caution. The same applies to 
TABLE 3. Gender Segregation by Industrial Sector

\begin{tabular}{|c|c|c|c|c|}
\hline \multirow[t]{2}{*}{ NACE sectors } & CEEC-10 & EU-15 & CEEC-10 & EU-15 \\
\hline & \multicolumn{2}{|c|}{ Male percentage } & \multicolumn{2}{|c|}{ Female percentage } \\
\hline Construction & 88 & 91 & 12 & 9 \\
\hline Fishing etc. & 85 & $\mathrm{n} / \mathrm{a}$ & 15 & $\mathrm{n} / \mathrm{a}$ \\
\hline Mining & 83 & 84 & 17 & 16 \\
\hline $\begin{array}{l}\text { Electricity, gas, and } \\
\text { water supply }\end{array}$ & 78 & 84 & 22 & 25 \\
\hline $\begin{array}{l}\text { Transport, storage, } \\
\text { and communications }\end{array}$ & 69 & 75 & 31 & 25 \\
\hline Agriculture etc. & 64 & 66 & 36 & 34 \\
\hline Manufacturing & 59 & 73 & 41 & 27 \\
\hline $\begin{array}{l}\text { Real estate, renting, } \\
\text { and business }\end{array}$ & 55 & & 45 & \\
\hline $\begin{array}{l}\text { Public administration, } \\
\text { defence, and social } \\
\text { security }\end{array}$ & 54 & 56 & 45.7 & 44 \\
\hline $\begin{array}{l}\text { Wholesale and retail } \\
\text { trade }\end{array}$ & 47 & $(47)$ & 53 & (53) \\
\hline $\begin{array}{l}\text { Other community } \\
\text { social and personal } \\
\text { services }\end{array}$ & 41 & 44 & 59 & 56 \\
\hline Financial intermediation & 37 & 58 & 63 & 42 \\
\hline Hotels and restaurants & 35 & $(47)$ & 65 & $(53)$ \\
\hline Education & 24 & (25) & 76 & (75) \\
\hline Health and social work & 21 & (25) & 79 & (75) \\
\hline All & 56 & 56 & 44 & 44 \\
\hline
\end{tabular}

Note: EU-15: European Foundation survey data for 2000 (Fagan and Burchell, 2002: 24). Figures in parentheses show amalgamated NACE.

Source: CEEC-10, Country Reports using LFS 2001, Pollert and Fodor (2004).

gender disaggregated pay data by occupation. A further difficulty is that, at present, apart from Estonia and Latvia, CEECs present data as gross monthly wages, whereas EU-15 data indicate bourly wages, although similarity in male and female working hours in CEECs makes this less of a problem (see below).

Gender pay ratios for pre-transition and early (1990-92), mid (1996) and late (2001) post-transition, can be compared using the UNICEF (1999) study entitled Women in Transition and our own data (Pollert and Fodor, 2004: Table 16). There was an initial major improvement from the communist period, when women earned between 66 and 74 percent of male earnings, to the early 1990s, when the proportion rose to between 73 and 79 percent. But in the mid-1990s, this dropped again, typically to 
between 68 and 70 percent. There was some recovery by 2001, but only in some cases was the ratio better than in the early 1990s. The exception to these sharp fluctuations was Slovenia, where women's earnings were 87 percent of men's in 1987, and after a 2-percent drop in 1996 rose to 89 percent in 2001.

The pay gap in the communist period reflected job segregation, with men working in the better paid, heavy, 'core' industries and women in poorly paid 'peripheral' or 'light' industries, services, and administration (Pollert, 2003: 332). There is some evidence that the early narrowing of the pay gap was related more to male job loss or pay cuts in the early 1990s, when managers were first free to cut labour costs in largely maledominated state enterprises, than to women's pay increases, although it is possible that educated women had a short-lived opportunity to use their qualifications to enter higher paid jobs (Grajek, 2001: 13). While several countries showed a slower improvement in 1996, Bulgaria, Estonia, Hungary and Slovenia evidenced deterioration. Since then, the trends have varied: the pay gap has widened again in the Czech and Slovak Republics and has narrowed, but only slightly, in most other countries, although substantially more so in Bulgaria and Lithuania. Variation among the CEECs has been clear over a sustained period. The pay ratio in Slovenia has remained steadily better than in all other CEECs as well as the EU-15; in Hungary and Poland, it has found an intermediate level not vastly different from western ratios for the time; but in the Czech and Slovak Republics, the pay ratio was very poor. This pattern continues.

Our evidence shows that the CEEC-10 pay gap is bigger than that in the EU-15, contrary to suggestions that the 'the gender pay gaps in the accession countries are similar to, or even smaller than, those prevailing in the current European Union Member Countries' (EC, 2003: 12). The EU-15 gap was 16 percent in 2002, whereas in the CEECs, it averaged 20 percent in 2001 (see Table 4). The difference may be partly attributable to the different basis of earnings data (hourly in the EU-15 and monthly in the CEEC-10), but because gender differences in working time are small in the latter, this is unlikely to explain more than half the difference. Some four countries still have women earning only around threequarters of men's gross monthly wages (Bulgaria, the Czech and Slovak Republics and Estonia), the rest are around 80 percent, with Slovenia standing out at 89 percent. This follows an overall 3-percent improvement on 1995/96.

Sectoral analysis shows that in agriculture and fishing, employing only 10 percent of women in 2001, women's pay as a percentage of men's was between 80 and 87 percent. But the gap is large and deteriorating in the more feminized manufacturing sector and most private services. A general observation supporting the wide literature on the association 
TABLE 4. Women's Gross Monthly Pay as a Percentage of Men's by Sector, 1996 and 2001

\begin{tabular}{|c|c|c|c|c|c|c|c|c|c|c|c|c|}
\hline \multirow[t]{2}{*}{ Country } & \multicolumn{2}{|c|}{$\begin{array}{l}\text { Agriculture and Fishing } \\
\text { (NACE 1,2) }\end{array}$} & \multicolumn{2}{|c|}{$\begin{array}{c}\text { Industry } \\
\text { (NACE 3,4,5) }\end{array}$} & \multicolumn{2}{|c|}{$\begin{array}{l}\text { Manufacturing } \\
\text { (NACE 4) }\end{array}$} & \multicolumn{2}{|c|}{$\begin{array}{c}\text { Private services } \\
\text { (NACE } 7,8,9,10,11)\end{array}$} & \multicolumn{2}{|c|}{$\begin{array}{l}\text { Public sector } \\
\text { IACE } 12,13,14,15)\end{array}$} & \multicolumn{2}{|c|}{ All Sectors } \\
\hline & $1996^{a}$ & 2001 & 1996 & 2001 & 1996 & 2001 & 1996 & 2001 & 1996 & 2001 & 1996 & 2001 \\
\hline $\begin{array}{l}\text { Bulgaria } \\
\text { Czech }\end{array}$ & 72.9 & 79.3 & 71.9 & 77.0 & 71.1 & 68.3 & 82.5 & 85.9 & 92.0 & 80.0 & 68.9 & 76.7 \\
\hline Republic & 80.0 & 80.1 & 68.2 & 68.4 & 68.2 & 68.0 & 73.0 & 65.5 & 75.9 & 75.2 & 77.1 & 74.4 \\
\hline Estonia $^{\mathrm{b}}$ & 88.5 & 90.5 & 60.0 & 68.0 & 79.0 & 73.0 & 69.0 & 62.0 & 83.0 & 78.0 & 71.0 & 73.0 \\
\hline Hungary & 90.9 & 91.9 & 70.7 & 71.8 & 71.4 & 72.0 & 87.7 & 85.9 & 79.2 & 76.6 & 79.0 & 80.1 \\
\hline Latvia & 84.8 & 84.0 & 81.1 & 81.1 & 82.2 & 84.3 & 72.4 & 70.7 & 78.7 & 81.4 & 78.3 & 80.2 \\
\hline Lithuania & 81.7 & 89.2 & 80.7 & 77.1 & $\mathrm{n} / \mathrm{a}$ & 77.3 & $\mathrm{n} / \mathrm{a}$ & $\mathrm{n} / \mathrm{a}$ & $\mathrm{n} / \mathrm{a}$ & $\mathrm{n} / \mathrm{a}$ & 70.3 & 81.4 \\
\hline Poland & 111.6 & 99.4 & 73.5 & 73.9 & 77.7 & 78.2 & 80.1 & 79.4 & 82.8 & 85.4 & 80.0 & 81.8 \\
\hline Romania & $\mathrm{n} / \mathrm{a}$ & 103.9 & & 69.1 & $\mathrm{n} / \mathrm{a}$ & $\mathrm{n} / \mathrm{a}$ & $\mathrm{n} / \mathrm{a}$ & $\mathrm{n} / \mathrm{a}$ & $\mathrm{n} / \mathrm{a}$ & $\mathrm{n} / \mathrm{a}$ & 79.0 & 81.6 \\
\hline Slovakia & 74.5 & 81.8 & 69.4 & 67.9 & 68.6 & 68.7 & 82.0 & 66.1 & 81.0 & 78.2 & 74.5 & 74.1 \\
\hline Slovenia ${ }^{\mathrm{d}}$ & $\mathrm{n} / \mathrm{a}$ & 75.5 & $\mathrm{n} / \mathrm{a}$ & 80.8 & $\mathrm{n} / \mathrm{a}$ & 78.5 & $\mathrm{n} / \mathrm{a} /$ & 84.5 & $\mathrm{n} / \mathrm{a}$ & 84.5 & 85.0 & 89.2 \\
\hline Average & 81.9 & 87.5 & 71.7 & 73.5 & 73.4 & 74.2 & 77.8 & 75.0 & 81.6 & 79.9 & 75.9 & 79.6 \\
\hline
\end{tabular}

Notes: a 1995 for Lithuania (1994 for Industry), Latvia, Romania, and Slovenia; 1999 for Poland.

${ }^{\mathrm{b}}$ Hourly pay.

${ }^{c}$ Figures for Industry, Services, and Public sector are weighted for populations.

d 2001: Industry includes construction (NACE 6), which inflates the figure (women's earnings are 119 percent of men's). Disaggregated figures are not available for Services and the combined figure is given for both private- and public-sector columns. Women's pay relative to men's is higher in public than in private services, which slightly inflates the CEEC average for private services and deflates the public-sector average.

e CEEC unweighted average. Calculation for 1996 is based on combined 1995 and 1996 figures. Poland has been omitted since 1999 is regarded as non-comparable. The average provides only indicative trends, since calculations exclude some countries for some years in which data were not available. Weighted average for 2001: 81.0 percent. 
between feminization and under-valuation of jobs, skills, and pay is that the more female the sector, the larger the pay gap, or, as in the case of the public sector in the CEECs, the lower the absolute level of wages. In manufacturing, which was 41 percent female in both 1995 and 2001, women earned only 74 percent of men's pay in 2001, a mere 1-percent improvement on 1996. The picture for manufacturing is worst in Bulgaria, the Czech Republic and Slovakia, where women earned only 68 percent of men's monthly pay. It has stagnated or worsened since 1995/96 in Bulgaria, the Czech Republic, Estonia and Slovakia, with only slight improvement in Hungary and Latvia.

There has been some variation between and within countries in the public sector. For example, in Lithuania between 1995 and 2000, the ratio improved from 85 to 97 percent in education, but declined from 86 to 84 percent in health; in the Czech Republic, the ratio in these sectors was stable at the much lower 70 and 68 percent. But overall, the public-sector pay gap grew by almost 2 percent from 1995/96 to 2001. Only two countries (Latvia and Poland) showed any improvement and the rest stagnated or deteriorated, with Bulgaria showing a 12 percent drop from what had been a good equality record of 90 percent of men's pay. The public sector has paid poorly since 1989 (Pollert, 1999), but lack of equal opportunities policies must play a part if comparison is made with the EU-15, where the pay gap had closed to 12 percent in 2002 (EC, 2003: 10), largely because gender monitoring and equal pay policies are most clearly implemented in the public sector.

In (private) services, the pay gap worsened from 78 to 75 percent of male pay between 1995/96 and 2001. The most serious deterioration appears to be in Slovakia (from 82 to 66 percent, although the country team advises caution in comparing the two periods), in the Czech Republic (from 73 to 66 percent) and in Estonia (to 62 percent). In finance, the pay gap has widened in every country, especially in the Czech Republic and Slovakia, where it grew to 50 percent in 2001. This strengthens the hypothesis that as women's representation declines here, men are taking the higher-paying jobs. The same seems to be happening in retail in some countries: in the Czech Republic, Estonia and Lithuania, women's representation has declined, while the pay gap has grown, suggesting they are losing out in the higher echelons (Pollert, 1995). In hotels and restaurants, only Lithuania showed a marked improvement for women; elsewhere the ratio became worse, especially in Latvia. Here, women's employment increased proportionately over our period, so it appears that expansion was into feminizing, poorly paying jobs.

A gender polarization between 'good' and 'bad' jobs seems to be occurring. For example, in Bulgaria, women managers' pay was more than 90 percent of men's in 1995, but this deteriorated to about 60 percent by 2001. The same occurred in Slovakia and the Czech Republic, 
although the gap reduced among managers in Estonia, and there was no change in the other countries for which data are available. Among technicians and semi-professionals, grades at which between 11 and 25 percent of women workers were employed in 2001, the wage ratio ranges from 60 percent in Lithuania to 85 percent in Latvia. Among professionals, women seem to be making less money relative to men compared to the mid-1990s in the Czech Republic, Hungary, Slovakia and Estonia. For example, in Hungary, women's relative pay fell from 70 to 64 percent from 1997 to 2001. This indicates the segregation of women within the professions and men's increasing colonization of higher paying, more privileged positions. Women's high educational attainment is not improving their pay prospects. For example, Slovene research shows that at different educational levels women are paid less than men (around 88 percent) and that the pay gap increased between 1991 and 2001 for women with university or post-university degrees and among skilled and highly skilled workers. Only among the unskilled has the gap diminished. In the Czech Republic, women university graduates earn the same as men with a secondary-school certificate (Cermaková, 1999: 134).

These findings significantly qualify the suggestion that 'the gender pay gaps in the Accession Countries [have] been declining over the last decade' (EC, 2003: 12). They also caution against drawing the wrong conclusions from the European Foundation's findings on the income gap in the CEECs. This analysis (European Foundation, 2002: 5) shows that in the EU-15 in 2000, 30 percent of men were in the top 25 percent of the income distribution as against only 13 percent of women; in the CEEC-10, the proportions were 29 and 20 percent in 2001. In the bottom 25 percent, men accounted for 13 percent in the EU-15 and women for 34 percent; in the CEEC-10, the figures were 20 and 28 percent. However, income is based on monthly earnings and the similarity in working hours for men and women in the East makes comparison with monthly EU-15 earnings misleading regarding the hourly pay gap, because of the wide gender differences in working hours in the West. In 2002, 33.5 percent of EU-15 women worked part-time, compared with 6.6 percent of men (18.2 percent for both sexes). Additionally, high overtime working in some countries means full-time men work on average seven hours a month longer than women (and as much as eleven hours in the UK and nine in Germany) (EC, 2003: 28). In the CEEC-10, the working-time gap between men and women is only two hours on average, while only 7.2 percent of all employees work part-time and the difference between men and women is small (5.2 and 8.6 percent, respectively). Although part-time work did increase in the immediate post-transformation period, the change was small, and in some countries, such as Slovakia, the incidence has recently declined. 


\section{Conclusions}

Some 15 years after the break with the communist past, the UN GDI shows that women's advanced gender-equality legacy in the international ranking order has been eroded. Factors responsible include the decline in social support for families, the drop in the real value of social benefits, the rising costs of childcare, and absence of work-family harmonization policies - in sum, the reversal of those communist social policies which benefited women workers and which are advanced now as favouring 'work-life balance'. The contribution of women's employment and thus earnings to their gender equality development was one element in the high GDI rankings of former CEECs, and this has clearly been cut. Although women still constitute around 45 percent of the employed, their labour force activity rates have declined and they are overrepresented among the unemployed.

However, to subsume all of post-communist Europe within one model is a distortion. An important part of this study has been to highlight not only common patterns across the CEE, but also very significant national differences arising from different economic structures and histories. Sectoral structures differ, most obviously between agricultural and industrial economies, as well as variations on the command-economy model. While post-communist transformation has entailed the common experience of a structural adjustment programme, severe recession, and job loss, unemployment rates for men and women vary. In the Czech Republic, Poland, and recently in Slovenia, it is higher for women than for men, as is the case in the EU-15. In other countries, such as Bulgaria and Lithuania, where this pattern pertained until 1995, female unemployment is now lower, although this may be due to lower female activity rates. Even within the broad pattern of decline in agriculture and industry and growth in services, there have been exceptions, with agriculture expanding in Romania and industry in Hungary. Nevertheless, apart from falling employment for both men and women and the decline in women's activity rate noted above, other common patterns have emerged from this analysis which are cause for concern in the current phase of European expansion and integration.

The European Foundation $(2002,2003)$ and the EC (2003) studies suggest that, in many ways, the gender-equality situation in eastern Europe is similar to or better than the West: similar, but less sexual segregation and a similar, but smaller pay gap. One might expect this to be the case, considering that the 'worker-mother' model was intrinsic to communist labour-market policy, with women entering more professional and senior positions than in the West, albeit within a gendersegregated context. However, the national LFS data, presented for the first time here, challenge these assumptions. First, sexual segregation in 
eastern Europe has a different shape to that in the West, but is no less extreme. Women do have a stronger presence in 'male' industries, as is to be expected from the postwar communist industrialization policy, but there is greater female crowding in the public sector than in the West. This is a low-paying sector, and although the pay gap has been narrower here than in some sectors, it is widening. In terms of vertical segregation, there are smaller proportions of women in the top occupations in most CEECs than in the West, and despite some improvements there is little sign of less vertical segregation.

Expansion of private services has benefited men rather than women, whose proportion of employment in the sector fell from between half and two-thirds in 1990 to less than half in 2001 . The proportion of the male labour force employed in the sector grew from about 20 to 30 percent in this period, a far larger increase than for women. This is in striking contrast to the public sector, where the share of men's employment grew by only 1 percent (to become 16 percent in total). There was a 20 percent fall in the female proportion in financial mediation, and even in retail there was a fall from 68 to 54 percent.

Our data show that the pay gap is larger than in the EU-15, not smaller as is usually assumed. Although there were improvements in the early transition years, the gap narrowed by only about 1 percent on average in the decade up to 2001, and actually widened in some countries, such as the Czech and Slovak Republics. In four countries (Bulgaria, the Czech and Slovak Republics and Estonia), women still earn only around threequarters of men's gross monthly wages; elsewhere, the proportion is around 80 percent, with Slovenia standing out at 89 percent. Among top professionals (ISCO-88, Group 2), women's relative pay has worsened in some countries (the Czech Republic, Hungary, Slovakia and Estonia), despite the evidence of high and increasing levels of educational attainment among CEE women and a continuing legacy of employment in the professions and semi-professions. Examination of the wage gap within occupations shows a widening in the professions since the mid-1990s: women are well represented in them, but it is clear that the occupations themselves are becoming increasingly vertically segregated, with men taking the better paid posts.

EU accession has undoubtedly been a progressive force counteracting the erosion of gender equality, women's rights, and support for families during the transition to capitalism. Existing gender-equality legislation has been updated, for example, by specifying equal pay for work of equal value rather than just for equal work and by prohibiting indirect as well as direct discrimination. Most countries have revised their labour codes, implemented gender-equality laws, and established institutional structures to monitor and enforce legislation. However, most training programmes target the unemployed and few target women. Beyond the problem of 
unemployment, there is no evidence of any conception of 'positive action' programmes, either in training or recruitment, to counteract the effects of the occupational segregation noted in this study. In general, however, all countries demonstrate some important advances in policy, including banning sex-typed advertising and recruitment and discrimination on such grounds as sex, family position and sexual orientation.

The chief problem is the enormous gap between institutional structures, legislation, and official policy on equality on the one hand, and actual practice on the other. If legislation and enforcement on discrimination and equal pay, for example, were beginning to work, then there would be less evidence of continuing and often widening pay gaps, women's disproportionate unemployment, and sectoral and occupational sex segregation. Our country reports all address the dichotomy between rhetoric and reality. Many refer to broader problems associated with the transition from command to capitalist economies. A key theme is that gender equality has been relegated to a superfluous concern in the grand march towards economic 'reform'. Even the falling birth rate has hardly registered as a danger signal of this neglect. The reports are also not optimistic about the rise of 'civil society' as a wider context for promoting gender equality. Neither men nor women appear concerned with sex equality; and although non-governmental organizations have sprung up everywhere, they represent very few people and tend to deal with the effects, rather than the causes, of inequality. Trade unions are weak and few are concerned with women's issues. In this context, it is not surprising that equality legislation is flagrantly violated. Employers are either unaware of the law or disregard it, while workers are also often unaware, or frightened of victimization and more concerned to keep their job than to protect their rights.

The barriers to progress are that conventions, laws and formal accession processes may become tokens subordinated to the economic accession criteria of free competition. Yet without the EU, it is likely that women's gender legacy would have no protection at all. One positive development in the CEECs is the cooperation of the unions, and other components of the equal opportunities policy apparatus, with international bodies such as the International Labour Organization, and with each other. Nevertheless, the creation of institutions and policies to satisfy EU requirements is far from sufficient to change practice. Further research is needed, including more at the microlevel, and it requires wide dissemination to create further pressure for change.

\section{ACKNOWLEDGEMENTS}

The research for this project was funded by European Foundation for the Improvement of Living and Working Conditions (Project No. 9285) and was 
completed in February 2004. Thanks to the 10 country teams below and to Éva Fodor, Acting Head of Department of Gender Studies, Central European University, Budapest, who co-wrote the final report. The views expressed here are my own and not necessarily those of the European Foundation.

National report authors: Bulgaria: Lilia Dimova; Czech Republic: Marie Čermaková, Alena Křǐžková; Estonia: Krista Loogma; Hungary: Éva Berde, Judit Nosztrai; Latvia: Liene Jeruma; Lithuania: Vida Kanopiene; Poland: Wieslawa Kozek, Anna Kwiatkowska; Romania: Liliana Voicu, Speranța Pîrciog, Radu Necșuliuț; Slovakia: Ludovít Czíria, Margita Barosová, Anna Reinerová; Slovenia: Aleksandra Kanjuo Mrčela, Nvenka Cernigoj Sadar.

\section{NOTES}

1 The European Foundation will publish the final report and will make the country reports available on its web-site: http://www.eurofound.eu.int

2 The HDI, created in 1990, uses life expectancy at birth (representing a long and healthy life); a composite indicator for educational attainment (the adult literacy rate and educational enrolment), representing knowledge; and real per capita income (based on GDP and more recently, US dollar purchasing power parity), representing standard of living. In UNDP (1991), separate HDIs were calculated for men and women based on life expectancy, adult literacy, wage rates, employment levels, and mean years of schooling, and an overall gender-sensitive HDI was developed for 30 countries. The GDI was introduced for all countries in 1995. The greater the inequality, the lower the GDI value. Another measure representing gender equality in the area of political power is the Gender Empowerment Measure (UNDP, 1995).

3 Another index, the Relative Status of Women, places CEECs even higher, outstripping advanced Nordic countries (Dijkstra and Hanmer, 2000: 69).

4 Many countries refer only to registered unemployed for 1990, but then use the wider International Labour Organization definition, covering all who are out of work, want a job, have actively sought work in the previous four weeks and are available to start work within the next fortnight, or who are out of work and have accepted a job that they are waiting to start in the next fortnight.

5 This pattern is similar to that in the EU-15 in 2001, where women formed 42.8 percent of total employment, but 50.6 percent of unemployment, while men comprised 57.2 percent of employment, but 49.4 percent of unemployment (calculated from EC, 2002: 173).

\section{REFERENCES}

Čermaková, M. (1999) 'Gender Differences Among Economically Active University Graduates’, Czech Sociological Review 7(2): 127-44.

Dijkstra, A.G. and Hanmer, C. (2000) 'Measuring Socio-Economic Gender Inequality: Toward an Alternative to the UNDP Gender-Related

Development Index', Feminist Economics 6(2): 41-75.

EC (2002) Employment in Europe 2002. Luxembourg: OOPEC. 
EC (2003) Commission Staff Working Paper: Gender Pay Gaps in European Labour Markets - Measurement, Analysis and Policy Implications. Brussels: SEC.

Einhorn, B. (1993) Cinderella Goes to Market. London: Verso.

European Foundation (2002) Working Conditions in Candidate Countries and the European Union, Résumé. Dublin: European Foundation.

European Foundation (2003) Working Conditions in the Acceding and Candidate Countries of the European Union. Luxembourg: OOPEC.

Eurostat (2002) Employment and Labour Market in Central European Countries, Theme 3, Population and Social Conditions. Luxembourg: OOPEC.

Fagan, C. and Burchell, B. (2002) Gender, Jobs and Working Conditions in the European Union. Luxembourg: OOPEC.

Grajek, M. (2001) 'Gender Pay Gap in Poland', WZB Discussion Paper FS IV 01-13. Berlin: Wissenschaftszentrum Berlin.

Pollert, A. (1995) 'Women’s Employment and Service Sector Transformation in Central Eastern Europe: Case Studies in Retail in the Czech Republic', Work, Employment and Society 9(4): 629-56.

Pollert, A. (1999) Transformation at Work in the New Market Economies of Central Eastern Europe. London: Sage.

Pollert, A. (2003) 'Women, Work and Equal Opportunities in Post-Communist Transition', Work, Employment and Society 17(2): 331-57.

Pollert, A. and Fodor, É. (2004) 'Final Report: Gender, Work and Employment in Ten Accession Countries of Central Eastern Europe to the EU', mimeo. Dublin: European Foundation.

UNDP (1991) United Nations Development Programme Human Development Report. New York: United Nations.

UNDP (1995) United Nations Development Programme Human Development Report. New York: United Nations.

UNDP (2001) United Nations Development Programme Human Development Report. New York: United Nations.

UNDP (2003) United Nations Development Programme Human Development Report. New York: United Nations.

UNICEF (1999) Women in Transition, MONEE Project, CEE/CIS/Baltics, Regional Monitoring Report, No. 6. Florence: UNICEF.

\footnotetext{
ANNA POLLERT is Professor of the Sociology of Work at London Metropolitan University.

ADDRESS: Working Lives Research Institute, London Metropolitan University, 166-220 Holloway Road, London N7 8DB, UK.

[e-mail: a.pollert@londonmet.ac.uk]
} 